\title{
TWO-STRAP RF ANTENNA IN URAGAN-2M STELLARATOR
}

\author{
A.V. Lozin', Yu.V. Kovtun ${ }^{1}$, V.E. Moiseenko ${ }^{1}$, S.M. Maznichenko ${ }^{1}$, M.M. Kozulia ${ }^{1}$, \\ V.B. Korovin ${ }^{1}$, A.N. Shapoval ${ }^{1}$, E.D. Kramskoy ${ }^{1}$, R.O. Pavlichenko ${ }^{1}$, N.V. Zamanov ${ }^{1}$, \\ M.M. Makhov ${ }^{1}$, A.Yu. Krasyuk, Y.V. Siusko', A.I. Tymoshenko ${ }^{1}$, V.M. Listopad ${ }^{1}$, T. Wauters ${ }^{2}$ \\ Ye. Kazakov', J. Ongena ${ }^{2}$
}

\section{${ }^{1}$ Institute of Plasma Physics NSC “Kharkov Institute of Physics and Technology”, Kharkiv, Ukraine; ${ }^{2}$ Laboratory for Plasma Physics, ERM/KMS, Brussels, Belgium}

\section{E-mail: Ykovtun@kipt.kharkov.ua}

A unshielded two-strap antenna had been installed in Uragan-2M. A vacuum chamber inner walls conditioning regime with the two-strap antenna is studied in a weak magnetic field. Plasma with the density $n_{\mathrm{e}} \sim(0.2 \ldots 0.95) \cdot 10^{12} \mathrm{~cm}^{-3}$ and sustained. The RF frequency was $\mathrm{f}_{0} \sim 5 \mathrm{MHz}$, RF plasma was sustained in stationery magnetic field $B_{0} \approx 0.01 \mathrm{~T}$, at hydrogen pressure range $3 \cdot 10^{-3} \ldots 3 \cdot 10^{-2} \mathrm{~Pa}$.

PACS: 52.55.Hc; 52.50.-b

\section{INTRODUCTION}

The biggest stellarator Wendelstein 7-X (W7-X) will resume its work in early 2022 [1,2]. New installed equipment will include the ion-cyclotron plasma heating (ICRH) system [3, 4]. The ICRH system includes a twostrap antenna which shape is fitted for the last closed magnetic surface of the standard magnetic configuration. This system is tunable and can operate at frequencies of 25...38 MHz.

In stellarator Uragan-2M (U-2M) plasma is created and heated with radio-frequency (RF) methods at ioncyclotron frequency range during regular operation. Single and double frame, crankshaft, three-half-turn, and four strap antennas [4-8] were used in previous experimental studies. Newly made the two-strap antenna is recently installed at $\mathrm{U}-2 \mathrm{M}$. Its shape is similar to $\mathrm{W}-7 \mathrm{X}$ ICRH antenna and the main distinction is that it is just smaller. The main research tasks for the U-2M two-halfturn antenna are the RF discharge plasma production (start-up) for further regular discharges, and plasma sustain in different RF vacuum chamber wall conditioning regimes.

The Uragan-3M (U-3M) and U-2M vacuum chambers are RF conditioned in weak magnetic fields at frequencies up to $10 \mathrm{MHz}[6,9,10]$. The conditioning method was proposed in Ref. [11]. The frame and threehalf-turn antenna were used for wall conditioning at U$2 \mathrm{M}$ in those experiments. Hence it will be interesting to study RF conditioning discharge of the new two-strap antenna. It will allow us to work out the possibility of two-strap antenna usage in the conditioning regime and to test the antenna, its units, and matching device while working with plasma load.

The paper presents a multifunctional unshielded twostrap antenna description and its first usage in wall conditioning regime in $\mathrm{U}-2 \mathrm{M}$. The two-strap antenna was used to create target plasma later experiments [12].

\section{EXPERIMENTAL SETUP}

$\mathrm{U}-2 \mathrm{M}$ device is a mid-size stellarator (torsatron) with twin helical coils $l=2$ having a small pitch angle, $m=4$ helical field periods and the additional toroidal field coils (Fig. 1) [5-8, 12-14]. The major torus radius is $R_{0}=1.7 \mathrm{~m}$, the average last closed flux surface minor radius is $\bar{a} \approx 0.2 \mathrm{~m}$. The maximum toroidal magnetic field strength with respect to mechanical stresses is $2.4 \mathrm{~T}$. The vacuum chamber is toroidal with inner radius of $r_{\mathrm{c}}=0.34 \mathrm{~m}$ and volume $V_{\mathrm{c}}=3.879 \mathrm{~m}^{3}$ (without volumes of the vacuum ports); torus surface area is $S=22.819 \mathrm{~m}^{2}$. The device chamber has 48 ports used for diagnostics, gas puffing, vacuum pumping, etc. The vacuum chamber is pumped with three turbomolecular pumps TMN-500 with a pumping speed of $0.5 \mathrm{~m}^{3} / \mathrm{s}$ equipped by the cryogenic ( $\mathrm{N}_{2}$ liquid) traps.

The RF complexes Kaskad-1 (K1) and Kaskad-2 (K2) use its $0.7 \mathrm{MW} \mathrm{RF}$ generators to produce and heat the plasma in pulses of $100 \mathrm{~ms}$ maximum duration with frequency tuneable between pulses in the range $f=1 . . .20 \mathrm{MHz}$ [15]. The $\mathrm{K} 1$ and $\mathrm{K} 2$ generators are of the same design: they are autogenerators. Each generator has four GI-26Apowerful tubes.

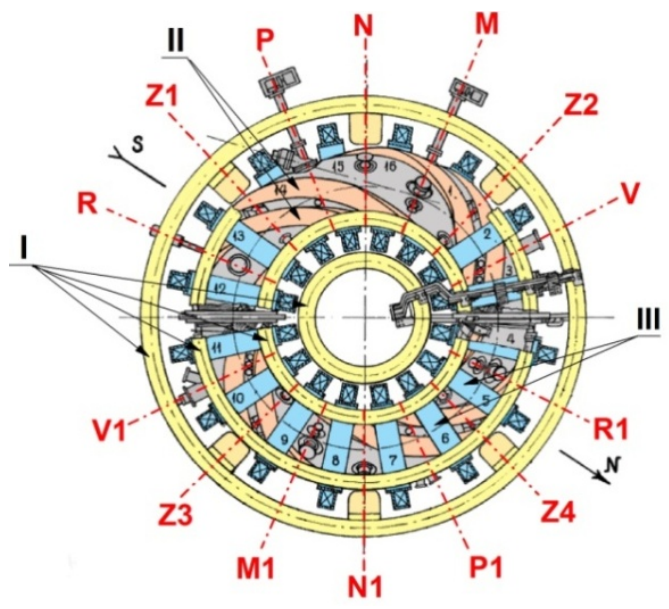

Fig. 1. Scheme of U-2M: I-Poloidal field coils; II-Helical field coils;

III-Toroidal field coils numbered 1-16

\section{TWO-STRAP ANTENNA}

The two-strap antenna (Fig. 2) consists of two parallel straps $60 \mathrm{~mm}$ wide and $600 \mathrm{~mm}$ long. The straps are made of $2 \mathrm{~mm}$ thick stainless steel. The emitting parts of the straps are adjusted to the plasma edge. They are placed $10 \mathrm{~mm}$ distance from the last closed magnetic surface for $\mathrm{U}-2 \mathrm{M}$ magnetic configuration with $\kappa_{\varphi}=0.32$ (Fig. 4). The 
$5 \mathrm{~mm}$ side edges of both straps are bent to inside along the whole length to provide mechanical stiffness. The distance between the straps in toroidal direction is $250 \mathrm{~mm}$.

The antenna (Fig. 3,a) is installed in the R1 crosssection between the toroidal coils 4 and 5 see (Fig. 1). The RF feed-troughs (see Fig. 2) are placed at the top and bottom R1 cross-section ports (see Fig. 3,a). To provide the ability of various electric connections, the antenna has four independent RF power feed-troughs which use fluoroplastic F-4 as isolator material. Water cooling of the RF power feed-troughs allows antenna usage in impulses up to $0.5 \mathrm{~s}$ long. The input elements of antenna (Fig. 5) feed-troughs are protected by quartz tubes $(3 \mathrm{~mm}$ thick and $35 \mathrm{~mm}$ diameter) to prevent breakdowns to the chamber wall and creation of plasma discharge inside the device ports.

The top parts of the antenna straps are protected by limiters (see Figs. 3,a, 5) since the plasma column crosses them in $\kappa_{\varphi}=0.32$ magnetic configuration. The limiters are installed on both sides of the antenna.

$\mathrm{U}-3 \mathrm{M}$ and $\mathrm{U}-2 \mathrm{M}$ experiments shown that plasma discharge causes an accumulation of metal impurities (Fe and $\mathrm{Cr}$ ) [16] that are supplied into the discharge by the RF antennas surfaces and vacuum chamber walls. So, to decrease the heavy impurities flow into plasma, the antenna and the antenna limiters are covered by the titanium nitride (TiN) film which is more resistant against arcing and sputtering. The spectroscopic measurements in experiments with titanium nitride covered antennas shown that titanium influx is $50 . . .70$ times less than iron and chromium influx from antennas without coating [17].

The main elements of the two-strap antenna and limiters are covered with titanium nitride coating. The TiN coating was plated in the way of vacuum arc titan plasma condensation in high purity $(99.99 \%)$ nitrogen atmosphere in the «Bulat-TNP4» device [18]. The evaporated material was titanium BT1-0. The antenna was installed on a rotary table in the range of two vacuum arc plasma sources. The pressure was $1 \cdot 10^{-2} \mathrm{~Pa}$ and a rotary table was under negative $1000 \mathrm{~V}$ potential, the plasma sources were turned to the pulsing regime, the antenna surface was cleaned for 5 min by titanium ions bombardment. Then negative potential was set to $200 \mathrm{~V}$, plasma sources worked in a stationary regime and the antenna surface was plated with a titanium layer for $5 \mathrm{~min}$. Then nitrogen was added into the chamber and its pressure was set at $2 \cdot 10^{-1} \mathrm{~Pa}$. TiN was plated during $20 \mathrm{~min}$. The resulting coating was $3 . . .4 \mu \mathrm{m}$ deep.

The two-strap antenna was connected to RF complex Kaskad-1. The RF power is transmitted from generators to antennas through feeders. They use coaxial radiofrequency cable RK-50-11-13. The cable is coupled with the generator and the load feeder of length $100 \mathrm{~m}$ and has the efficiency of $\eta=0.9 \ldots 0.75$ in the range of working frequencies $f=2 \ldots 14 \mathrm{MHz}$. The antenna is coupled to the feeders via a parallel LC circuit (see Fig. 3,b), created by the antenna inductance $L_{\mathrm{a}}$ and the attached capacitor $C$ (for dipole phasing). Such a circuit is tuned in resonance with the frequency of the generator anode circuit. When the resonance condition occurs, the current increases in the antenna circuit and the radiated power becomes higher. Also, the reactivity added by plasma is compensated in the antenna circuit and the active plasma resistance $R_{\mathrm{p}}$ is transformed into the value equivalent to the surge impedance of the feeder line $\rho_{f}=25 \ldots 50 \Omega$. So the two circuit system is formed by the generator and antenna circuits tuned at the same frequency. The matching device allows one to operate in the wide range of the antenna loading resistance values.
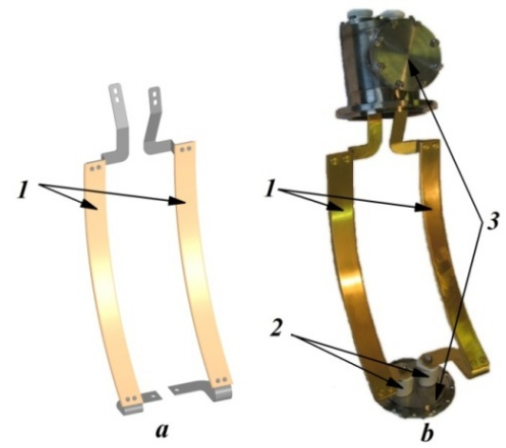

Fig. 2. Two-strap antenna:

Antenna model (a) and photo assembled with feedtroughs (b). 1 -straps; 2 -fluoroplastic isolators; 3 -elements of $R F$ feed-troughs
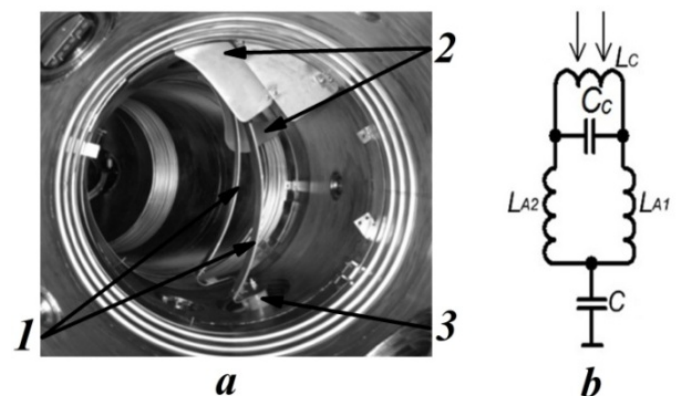

Fig. 3. Photo of the antenna inside the $U-2 M$ device (a) and the antenna unit electric scheme (b): 1 - straps;

2 - limiters from both sides of antenna;

3 -fluoroplastic isolator covered with a quartz tube

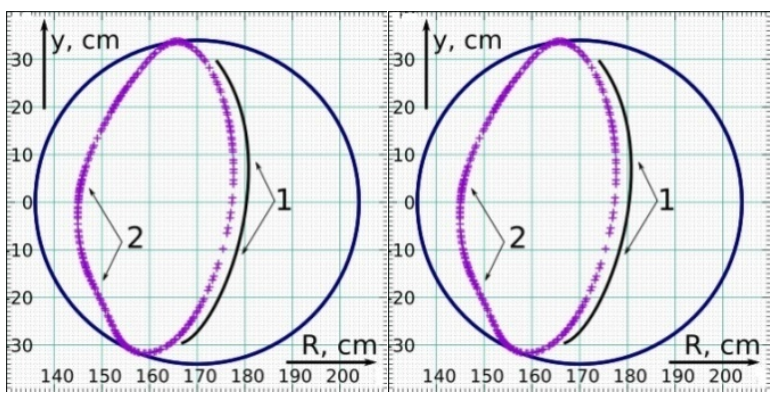

Fig. 4. Position of the two-strap antenna relative to the last closed magnetic surface: 1 - strap;

2 - last closed magnetic surface

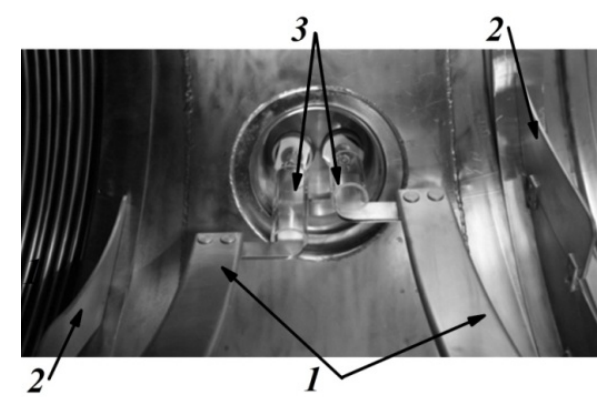

Fig. 5. Two-strap RF input leads inside device port (3) and limiters (2) installed from both sides of the antenna (1) 


\section{EXPERIMENTAL DETAILS}

The first run of the two-strap antenna was performed during the $\mathrm{U}-2 \mathrm{M}$ vacuum chamber conditioning regime in a weak magnetic field. This regime is described in Refs. [6, 9-11]. The frame [7] and two-strap unshielded antennas were used for wall conditioning. Both antennas are situated at the outer side of the plasma column: the frame antenna is in Z2 cross-section between $1^{\text {st }}$ and $2^{\text {nd }}$ toroidal magnetic coils (see Fig. 1), the two-strap antenna is in R1 cross-section (see Fig. 1). Two of the frame antenna conductors are oriented along the magnetic field and excite the slow wave. Longitudinal currents in the two-strap antenna are small and flow far from the plasma edge. So, weak slow wave excitation is expected.

The frame antenna is connected to the $\mathrm{K} 2$ RF generator. The generator frequency is $5.5 \mathrm{MHz}$, anode voltage $U_{K 2}=4 \mathrm{kV}$, input antenna RF power is up to $\approx 50 \mathrm{~kW}$. The two-strap antenna is connected to RF generator $\mathrm{K} 1$ with a frequency of $5 \mathrm{MHz}$. $\mathrm{K} 1$ anode voltage is $U_{K I}=6 \mathrm{kV}$, antenna input RF power is up to $\approx 70 \mathrm{~kW}$.

Hydrogen as the working gas is used at the pressure range from $3 \cdot 10^{-3}$ to $2 \cdot 10^{-2} \mathrm{~Pa}$. The $B_{0} \approx 0.01 \mathrm{~T}$ magnetic filed is created by helical, poloidal, and toroidal coils (see Fig. 1) in $\kappa_{\varphi}=0.32$ magnetic configuration.

The time dependence of the electron linear density is measured with a microwave interferometer (working frequency is $140 \mathrm{GHz}$ ) in R cross-section (see Fig. 1) $[19,20]$.

The spectral lines intensity time profile is registered with monochromator-spectrometer SOLAR TII (SOL instruments Ltd.) model MS7501i (Cherny-Turner optical scheme) with photomultiplier in P1 cross-section (see Fig. 1).

\section{EXPERIMENTAL RESULTS AND DISCUSSION}

The tuning of all systems was done to find optimal scenarios for RF-system functioning depending on neutral gas pressure before the first experiments. Also, the tuning aim is to find optimal working conditions for the two-strap antenna for the vacuum chamber inner surfaces conditioning scenario in a weak magnetic field. Such a Used wall conditioning method allows one to employ the same antennas and RF generators both for working regime plasma creation and heating without frequency change for the antenna and generator circuits during conditioning regime. The wave propagation and damping in weak magnetic fields are discussed in the paper [9].

The current scenario with two antennas is similar to the U-3M [9] and U-2M regime. The scenario includesthat the frame antenna produces plasma, and the fast wave antenna (e.g. three-half-turn antenna) increases plasma density. The scenario of the pulse RF wall conditioning is the following: the first frame antenna pulse, then the simultaneous operation of two antennas (frame and two-strap); and finally independent two-strap antenna operation. The full pulse duration of the RF discharge is $40 \mathrm{~ms}$ and the repetition rate is 5 pulse per second.

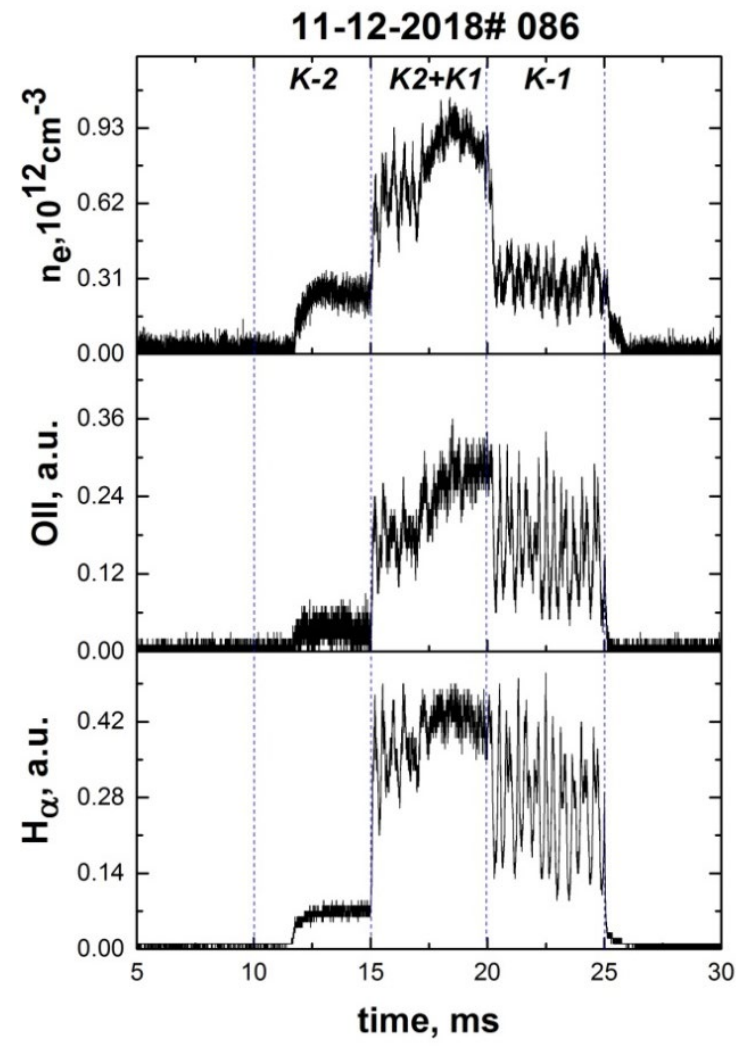

Fig. 6. Dependence of average plasma density and OII $(441.5 \mathrm{~nm})$ and $H_{\alpha}$ spectral line in time $(p=0.01 \mathrm{~Pa})$

The average plasma density and spectral lines time evolution is presented in Fig. 6. The frame antenna starts at $10^{\text {th }} \mathrm{ms}$ and the two-strap antenna - at $15^{\text {th }} \mathrm{ms}$. The frame antenna (K2 generator) works independently at the time interval $10 \ldots 15^{\text {th }} \mathrm{ms}$, creates plasma density up to $(1 \ldots 3) \cdot 10^{11} \mathrm{~cm}^{-3}$ and demonstrates a small neutral gas breakdown time (up to $3 \mathrm{~ms}$ ). The simultaneous antenna operation (generators K1 and K2) during $15 . .20 \mathrm{~ms}$ increases plasma density up to $n_{\mathrm{e}} \approx 1 \cdot 10^{12} \mathrm{~cm}^{-3}$. The two-strap antenna (generator K1) independently sustains plasma density $(1 \ldots 4) \cdot 10^{11} \mathrm{~cm}^{-3}$ for $20 \ldots 25 \mathrm{~ms}$ after K2 frame antenna turn off Fig. 6 shows average plasma density and $\mathrm{OII}_{\alpha} \mathrm{H}_{\alpha}$ lines emission during the simultaneous antennas work. Moreover, the presence of these oscillations or their absence (Fig. 7) depends on the discharge parameters: gas pressure, RF frequency and power. And it requires further research. Note that the low-frequency oscillations in RF discharges observed in the U-2M were previously considered in more detail in [21].

Fig. 7 shows OII and $\mathrm{H}_{\alpha}$ average line emission intensity dependence on $\mathrm{H}_{2}$ pressure. The low spectral lines intensity is observed during the frame antenna work. The line intensity $\mathrm{H}_{\alpha}$ and OII lines intensity increases several times during simultaneous operation of two antennas comparing to the frame antenna operation. The change of the line intensity during operation of the frame antenna and two antennas correlates with the average plasma density, i.e. with increasing density, an intensity increase is observed. The independent twostrap antenna work shows less, equal or higher emission intensity comparing to two antennas work depending on working gas pressure. 


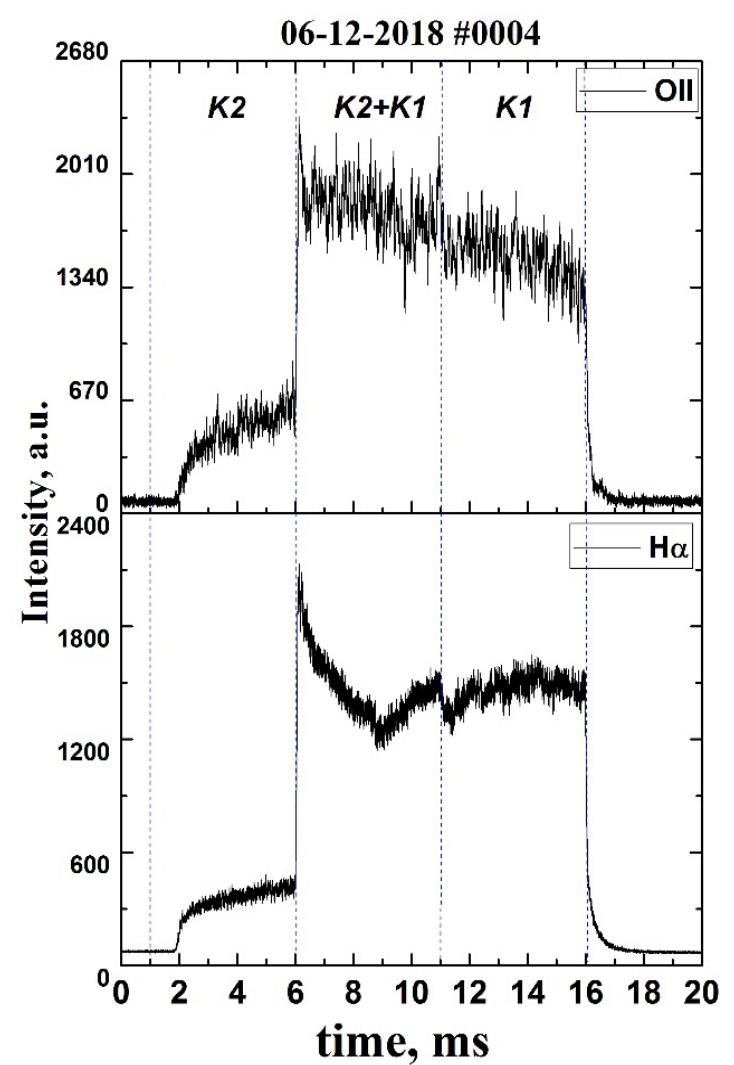

Fig. 7. Dependence of OII (441.5 nm) and $H_{\alpha}$ spectral lines from time. $(p=0.018 \mathrm{~Pa})$

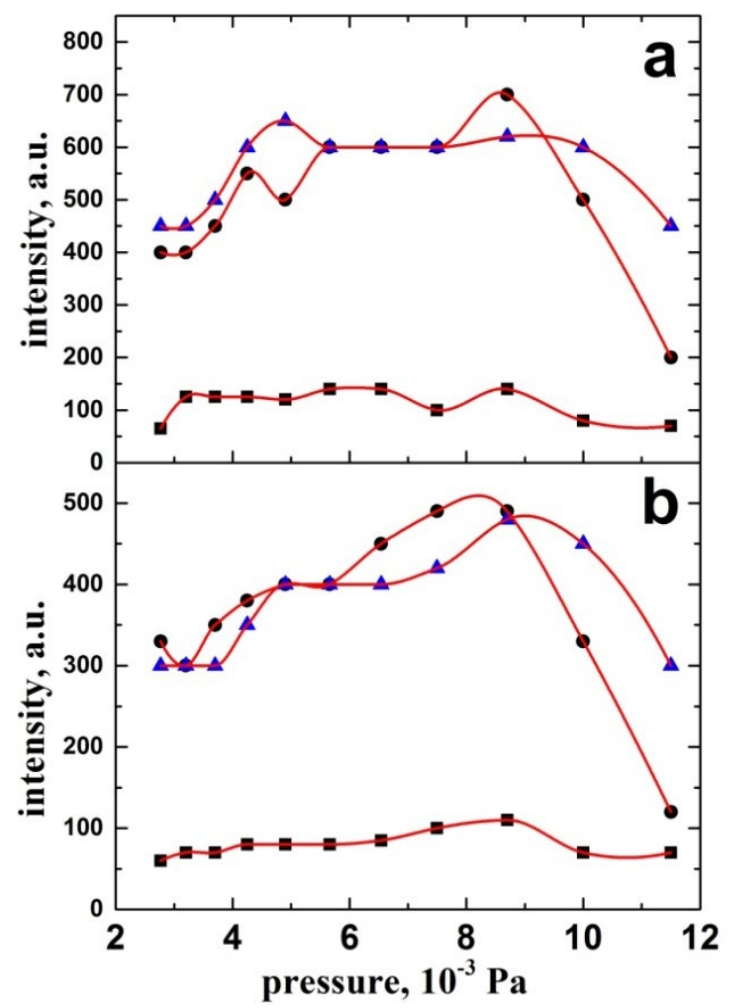

Fig. 8. Dependence of the emission intensity of the OII (a) $u H_{\alpha}$ (b) lines on the $H_{2}$ pressure. Black squareframe antenna (generator K2); black circle - two-strap (generators K2 and K1); blue triangle - two-strap antenna (generator K1)

The lines emission intensities considerably decrease at a pressure higher than $9 \cdot 10^{-3} \mathrm{~Pa}$ during both antennas and two-strap antenna work (Fig. 8). The later regime shows higher lines of emission intensity.

The obtained data shows that the two-strap antenna can be used for vacuum chamber inner surfaces conditioning regime in a weak magnetic field, both independently and with pre-ionization. The two-strap antenna in fact plays the role of three-half-turn antenna used earlier. the further experiments show [12] that the two-strap antenna can create plasma $n_{\mathrm{e}} \approx 1 \cdot 10^{12} \mathrm{~cm}^{-3}$ in a weak magnetic field $(0.01 \ldots 0.07 \mathrm{~T})$ without initial plasma created with the frame antenna. So the two-strap antenna can be used together with the frame antenna and independently.

\section{CONCLUSIONS}

The multifunctional unshielded two-strap antenna with four independent inputs is developed and implemented in U-2M.

The two-strap antenna operation is investigated in the vacuum chamber inner surfaces conditioning regime in a weak magnetic field in hydrogen atmosphere. The antenna matching device is tuned to optimum efficiency at plasma load conditions.

The joint operation of the two antennas, frame and two-strap, showes the average plasma density increase up to $\mathrm{n}_{\mathrm{e}} \approx 1 \cdot 10^{12} \mathrm{~cm}^{-3}$.

The RF discharge plasma can be sustained with only two-strap antenna during the whole impulse while the frame antenna is switched off.

\section{ACKNOWLEDGEMENTS}

This work has been carried out within the framework of the EUROfusion Consortium and has received funding from the Euratom research and training programme 2014-2018 and 2019-2020 under Grant Agreement № 633053. The views and opinions expressed herein do not necessarily reflect those of the European Commission.

\section{REFERENCES}

1. T. Klinger et al. Overview of first Wendelstein 7-X high-performance operation // Nuclear Fusion. 2019, v. 59 , p. 112004

2. T.S. Pedersen et al. First divertor physics studies in Wendelstein 7-X // Nuclear Fusion. 2019, v. 59, p. 096014.

3. J. Ongena et al. Study and design of the ion cyclotron resonance heating system for the stellarator Wendelstein 7-X // Physics of plasmas. 2014, v. 21, p. 061514.

4. B. Schweer et al. Development of an ICRH antenna system at W7-X for plasma heating and wall conditioning // Fusion Engineering and Design. 2017, v. 123 , p. $303-308$.

5. I.M. Pankratov et al. Behavior of RF Discharge Plasmas in the Uragan-3M and Uragan-2M Torsatrons // Contrib. Plasma Phys. 2010, v. 50, p. 520-528.

6. V.E. Moiseenko et al. RF plasma production and heating below ion-cyclotron frequencies in Uragan torsatrons // Nuclear Fusion. 2011, v. 51, p. 083036.

7. V.E. Moiseenko et al. Progress in stellarator research at IPP-Kharkov // Nukleonika. 2016, v. 61, p. 91-97. 
8. V.E. Moiseenko et al. Alfven plasma heating in stellarator Uragan-2M // Ukrainian Journal of Physics. 2017, v. 62, p. 311-317.

9. A.V. Lozin et al. Cleaning of inner vacuum surfaces in the Uragan-3M facility by radio-frequency discharges // Plasma Physics Reports. 2013, v. 39, p. 624-631.

10. V.E. Moiseenko et al. Wall-conditioning RF discharges in Uragan-2M torsatron // 36th EPS Conf. on Plasma Physics. 2009 (Sofia, Bulgaria, 29 June-3 July 2009), v. 33E (ECA), P-5.19.

11. N.I. Nazarov, V.V. Plyusnin, T.Yu. Ranyuk. Cleaning of surfaces by plasma in the Uragan-3 torsatron // Fizika Plazmy. 1987, v. 13, № 12, p. 1511-1515 (in Russian).

12. V.E. Moiseenko, M.B. Dreval, Yu.V. Kovtun, et al. First Experiments on ICRF Discharge Generation by a W7-X like Antenna in the Uragan-2M Stellarator // 22nd International Stellarator and Heliotron Workshop. 2019.

13. O.S. Pavlichenko. First results from the Uragan-2M torsatron // Plasma physics and controlled fusion. 1993, v. 35, SB, p. B223.

14. A.A. Beletskii, V.L. Berezhnyj, P.Ya. Burchenko, V.V. Chechkin, V.Ya. Chernyshenko, L.I. Grigor'eva, S.P. Gubarev, et al. First results of the renewed URAGAN-2M torsatron // Problems of Atomic Science and Technology. Series «Plasma Physics». 2008, № 6, p. 13-15.

15. V.B. Korovin, E.D. Kramskoy. Radio-frequency equipment for Uragan stellarators // Problems of Atomic Science and Technology. Series «Plasma Physics». 2015, № 6, p. 19-21.

16. L.I. Grigor'eva, V.G. Konovalov, N.I. Nazarov, V.V. Plyusnin, et al. A study of the mechanisms of metal impurity release during ICRF heating in the Uragan-3
Torsatron // Journ. of Nucl. Materials. 1989, v. 162, p. 458-461.

17. E.D. Volkov, J.F. Volkova, I.I. Demidenko, et al. Investigation of the erosion resistance of titanium nitride coatings and the possibility of their use for the protection of power-stressed units of thermonuclear installations // Fizika Plazmy. 1987, v. 13, № 10, p. 1256-1261 (in Russian).

18. A.I. Timoshenko, V.S. Taran, V.I. Tereshin. Plasma characteristics of two-step vacuum-arc discharge and its application for a coatings deposition // Problems of Atomic Science and Technology. Series «Plasma Physics». 2007, № 1, p. 179-181.

19. R.O. Pavlichenko, N.V. Zamanov, A.E. Kulaga. First measurements of line electron density in Uragan-2M plasmas via $140 \mathrm{GHz}$ heterodyne interferometer // Problems of Atomic Science and Technology. Series «Plasma Physics». 2017, № 1, p. 257-260.

20. R.O. Pavlichenko, N.V. Zamanov, A.E. Kulaga. A high speed $140 \mathrm{GHz}$ microwave interferometer for density fluctuation measurements in Uragan-2M stellarator // Problems of Atomic Science and Technology. Series «Plasma Physics». 2018, № 6, p. 332-335.

21. M.B. Dreval, A.M. Shapoval, A.A. Beletskii, R.O. Pavlichenko, F.I. Ozherel'yev, M.M. Makhov. Low frequency oscillations in U-2M conditioning RF discharges // Problems of Atomic Science and Technology. Series «Plasma Physics». 2018, № 6, p. 2445 .

\section{ДВУХПОЛУВИТКОВАЯ АНТЕННА СТЕЛЛАРАТОРА УРАГАН-2М}

А.В. Лозин, Ю.В. Ковтун, В.Е. Моисеенко, С.М. Мазниченко, М.М. Козуля, В.Б. Коровин, А.Н. Наповал, Е.Д. Крамской, Р.О. Павличенко, Н.В. Заманов, М.М. Махов, А.Ю. Красюк, Е.В. Сюсько, А.И. Тимошенко, В.М. Листопад, T. Wauters, Ye. Kazakov, J. Ongena

Введена в эксплуатацию на Урагане-2М многофункциональная неэкранированная двухполувитковая антенна. Отработана возможность работы двухполувитковой антенны в режиме чистки внутренних поверхностей вакуумной камеры в малом магнитном поле Плазма создавалась и поддерживалась с плотностью $\mathrm{n}_{\mathrm{e}} \sim(0,2 \ldots 0,95) \cdot 10^{12} \mathrm{~cm}^{-3}$. При рабочей частоте $\mathrm{f}_{0} \sim 5$ МГц ВЧ-плазма создавалась в стационарном магнитном поле $B_{0} \approx 0,01$ Тл при давлении водорода $3 \cdot 10^{-3} \ldots 3 \cdot 10^{-2}$ Па.

\section{ДВОНАПІВВИТКОВА АНТЕНА СТЕЛАРАТОРА УРАГАН-2М}

\section{О.В. Лозін, Ю.В. Ковтун, В.С. Моісеєнко, С.М. Мазніченко, М.М. Козуля, В.Б. Коровін, А.М. Шаповал, С.Д. Крамський, Р.О. Павличенко, М.В. Заманов, М.М. Махов, А.Ю. Красюк, С.В. Сюсько, O.I. Тимошенко, В.М. Листопад, T. Wauters, Ye. Kazakov, J. Ongena}

Введена в експлуатацію на Урагані-2М багатофункціональна неекранована двонапіввиткова антена. Відпрацьована можливість роботи двонапіввиткової антени в режимі чистки внутрішніх поверхонь вакуумної камери в слабкому магнітному полі. Плазма створювалась і підтримувалась густиною $\mathrm{n}_{\mathrm{e}} \sim(0,2 \ldots 0,95) \cdot 10^{12} \mathrm{~cm}^{-3}$. За робочої частоти $\mathrm{f}_{0} \sim 5$ МГц ВЧ плазма створювалась у стаціонарному магнітному полі $B_{0} \approx 0,01$ Тл за тиску водню $3 \cdot 10^{-3} \ldots 3 \cdot 10^{-2}$ Па. 